\title{
An Expression Analysis of crylAc IN BT Cotton Event MON531
}

\author{
Sajjad Ali Muhammad ${ }^{1}$, Ummar Asif Muhammad ${ }^{1}$, Tanzeela Bashir ${ }^{1}$ and Shaina Saeed ${ }^{1}$
}

\begin{abstract}
The presence of unauthorized germplasm not only has a negative economic impact on cotton productivity but also indicates a rapid development of resistance in target insect pests due to sub-lethal expression of the transgene. Here we report an assay for a comparative expression analysis of crylAc and ghtubl by standard curve method involving $\Delta \Delta C t$ values. The assay proves the validity of the Sybr Green I chemistry to be successfully used for the determination of transgene construct and expression. It can also be applied in sorting out the certified Bt cotton varieties (event MON531) from the un-authorized transgenic cotton germplasm.
\end{abstract}

Keywords—Bt cotton, expression analysis, crylAc; ghtubl, $\Delta \Delta C t$.

\section{INTRODUCTION}

Cotton genotypes are mostly developed through agrobacterium mediated transformation method and a crossing of $\mathrm{Bt}$ cotton germplasm with conventional elite varieties to introduce the gene cassette in them. Random rearrangement in the transgene nucleotide sequence, the order of the affiliated regulatory sequences as well as number of integrations of the transgene per genome copy resulting from these random hybridizations may result in the loss of transgene expression or even its complete silencing. Thus there is an urgent need to develop an assay to validate the type/construct and especially the comparative expression of the transgene in $\mathrm{Bt}$ cotton genotypes.

In order to detect the nature and construct of these nucleotide sequences, conventional and real time PCR techniques are applied. These techniques aim to screen out the controlling sequences such as cauliflower mosaic virus promoter sequence and Agrobacterium tumefaciens nopaline synthase terminator (T-Nos) while construct-specific detection targets the junctions between the adjacent elements of the transgene construct, i.e. the region between the inserted gene and promoter/terminator sequences (Fig. 1).

Institute of Molecular Biology and Biotechnology, The University of Lahore, Pakistan

* To whom all correspondence should be addressed. Dr. Muhammad Sajjad Ali,

Email: ma4u70@ hotmail.com ; Phone: 0308-7467839;

Postal Address: 1-Km Defence road, Institute of Molecular Biology and Biotechnology, The University of Lahore, Pakistan.
This study aims to develop an efficient and rapid assay of determining the true character of a $\mathrm{Bt}$ cotton genotype for the event MON531 and expression analysis of the crylAc with ghtub1(Gossypium hirsutum beta-tubulin)- a standard endogenous reference gene for cotton.

\section{MATERIALS AND METHODS}

Five commonly grown Bt cotton genotypes viz. Bt666, Bt886, CM555, SL1, and CM996 were purchased from local agricultural market in Multan in 2013. For each analytic sample, multiple DNA/RNA extractions were made by using Purelink Genomic DNA/RNA extraction kit (Invitrogen) according to the manufacturer's instructions. The conventional PCR mixes per reaction included $0.5 \mathrm{uM}$ of each primer, $5 \mu \mathrm{L}$ of diluted DNA in a final volume of $50 \mu \mathrm{L}$ of $1 \mathrm{x}$ PCR buffer. PCR conditions include initial denaturation at $95^{\circ} \mathrm{C}$ for 3 minutes, followed by $40-50$ cycles of denaturation for $30 \mathrm{~s}$ at $94^{\circ} \mathrm{C}$; 30s at $58^{\circ} \mathrm{C}$ (annealing) and for $30 \mathrm{~s}$ at $72{ }^{\circ} \mathrm{C}$ (extension). The final extension was carried at $72{ }^{\circ} \mathrm{C}$ for 10 min. The PCR amplicons were analyzed on $2 \%$ agarose /ethidium bromide gel (Vivantis) along with 100bp DNA ladder (Invitrogen). SuperScript ${ }^{\circledR}$ VILO cDNA Synthesis Kit and PowerUp ${ }^{\mathrm{TM}}$ SYBR ${ }^{\circledR}$ Green Master Mix (Thermo Scientific ${ }^{\mathrm{TM}}$ ) were used for RT qPCR. All the primers were synthesized by Vivantis Technologies. The primer sequences and their amplicon sizes are shown in Table 1.

The qPCR) for ghtubl and crylAc was performed in iCycler (Bio Rad) with a final volume of $50 \mu \mathrm{l}(20 \mu \mathrm{l}$ of water, $0.5 \mu \mathrm{M}$ of each primer, $3 \mu \mathrm{l}$ for each of five 10 -fold DNA dilutions of certified reference material (CRM), and $25 \mu$ of Sybr Green PCR Super Mix Universal (Invitrogen). The thermocycler (Bio-Rad PTC-06) was programmed with initial denaturation at $94^{\circ} \mathrm{C}$ for $3 \mathrm{~min}$. The cycling conditions for 40 cycles were set for denaturing at $94{ }^{\circ} \mathrm{C}$ for $30 \mathrm{sec}$, annealing at $58^{\circ} \mathrm{C}$ and extension at $72^{\circ} \mathrm{C}$ for $30 \mathrm{sec}$. The final extension was at $72^{\circ} \mathrm{C}$ for $10 \mathrm{~min}$ which was followed by melt peak curve analysis. The certified reference material (CRM) of MON531 event (AOCS 0804-C) which contains a single copy of the transgene crylAc was used as a control. Individual and independent runs for both the reference gene in CRM and the target gene in the sample variety were carried out in separate PCR vials in the same PCR run simultaneously. 


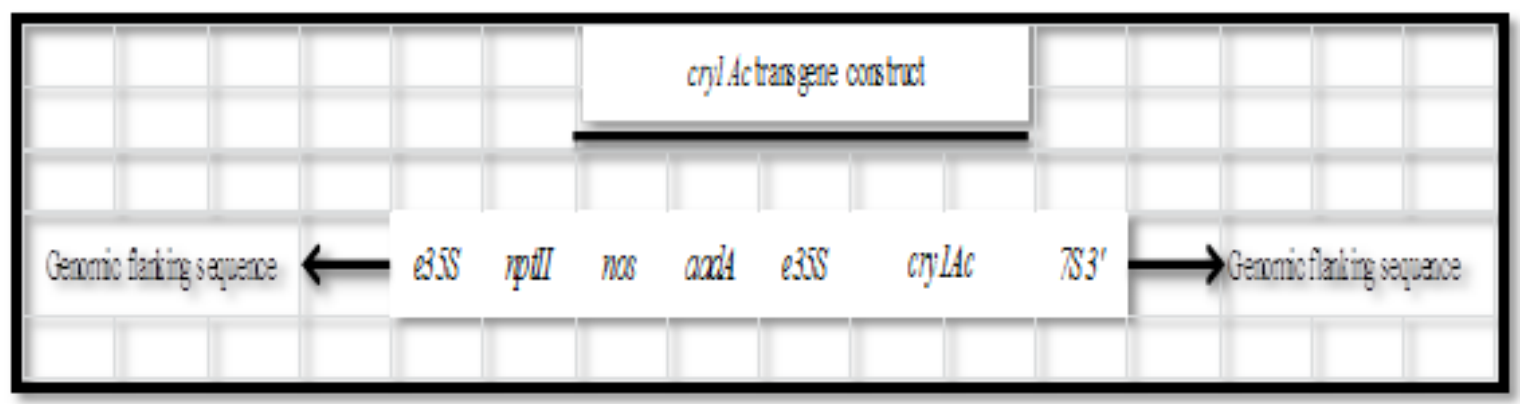

Fig. 1: The transgenic construct of MON531 and the target positions

TABLE 1. SEQUENCES AND AMPLICON SIZES OF THE PRIMERS

\begin{tabular}{|c|c|c|c|c|}
\hline Sr.No & Primer Name & Seq. $5^{\prime}$ to $3^{\prime}$ & $\begin{array}{c}\text { Amplicon } \\
\text { size }\end{array}$ & Reference \\
\hline & \multirow{2}{*}{$\begin{array}{c}\text { MON531 } \\
(\text { crylAc }+ \text { nos })\end{array}$} & F.GATACGGTGAGGGTTGCG & \multirow{2}{*}{577} & \multirow{2}{*}{ [7] } \\
\hline & & R.AAGTCATAGTTAAATAGCCCGATA & & \\
\hline \multirow{2}{*}{1} & \multirow{2}{*}{ ghtubl } & F.AAATCTAATGGAATAATTTGGATGT & \multirow{2}{*}{220} & \multirow{2}{*}{ [7] } \\
\hline & & R.ACTTAAGGTGTACTTGAAATTACT & & \\
\hline \multirow{2}{*}{2} & \multirow{2}{*}{ crylAc } & F.GCCAATGCCTCGTGATTGTTCTCTGC & \multirow{2}{*}{280} & \multirow{2}{*}{ [1] } \\
\hline & & R.GATTTGCGAGGCTGGCCAGCTCCACG & & \\
\hline
\end{tabular}

\section{RESULTS AND DISCUSSION}

MON531 event consists of crylAc along with 35S promoter, and nos terminator. In order to confirm that the varieties under trial are true-to-transgenic event, a sequence of DNA spanning from nos to crylAc was amplified (Fig.2).

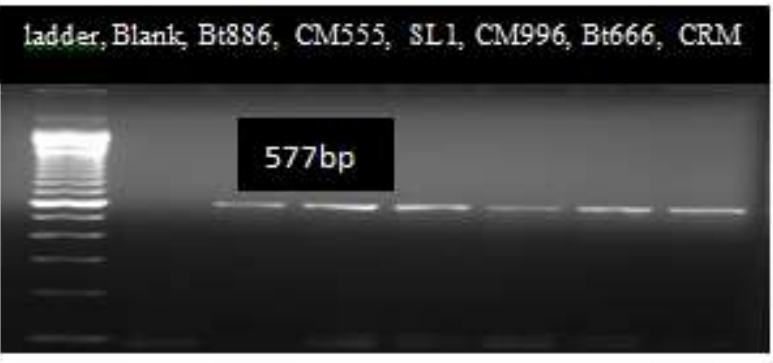

Fig.2: The amplification of crylAc+nos in cotton genome

The primer pair of crylAc+nos amplified a 577 bp DNA fragment containing both the $3^{\prime}$-end of $c r y l A c$ and $5^{\prime}$-end of nos. The fragment of cry1Ac+nos is specific for MON531 and its presence confirms the transgenic cotton event as MON531 [3].

\subsection{Calculation of the Comparative Gene Expression}

The relative expression ratio $(\mathrm{R})$ of a target gene with respect to a reference gene is calculated by a range of mathematical models based upon $\Delta \Delta \mathrm{Ct}$ values [6].
Relative expression ratio $(\mathrm{R})=\left(\mathrm{E}_{\text {target }}\right)_{\text {(control-sample) }}^{\Delta \mathrm{Ct}}{ }_{\text {target }}{ }^{\text {control-sample })} \div$ $\left(\mathrm{E}_{\mathrm{ref}}\right)^{\Delta \mathrm{Ct}}$ reference ${ }^{\text {(control-sample) }}$

The threshold cycle $(C \mathrm{~T}$, also known as $\mathrm{Cq}$ i.e. quantification cycle) is the cycle number at which the amount of amplified DNA sequence reaches a fixed threshold in a realtime PCR assay. Equation (1) describes the exponential amplification of the PCR:

$$
X \mathrm{~T}=X 0 \times(1+E \mathrm{X}) C \mathrm{~T}, \mathrm{X}
$$

where $X \mathrm{~T}$ is the amount of target molecules at threshold cycles, $X 0$ is the initial amount of the target molecule, $E X$ is the efficiency of the amplification and $C \mathrm{~T}, \mathrm{X}$ is the threshold cycle of the target DNA amplification [2].

Similar to equation (1), the equation for the reference gene (internal control gene) PCR reaction is

$$
R \mathrm{~T}=R 0 \times(1+E \mathrm{R}) C \mathrm{~T}, \mathrm{R}=K \mathrm{R}-
$$

where $R \mathrm{~T}$ is the amount of reference molecules at threshold cycles, $R 0$ is the initial amount of the reference molecule, $E \mathrm{R}$ is the efficiency of the amplification and $C \mathrm{~T}, \mathrm{R}$ is the threshold cycle of the reference DNA amplification.

From the equation of PCR amplification, the PCR efficiency $(E X, E R)$ can be obtained after the construction of the relative standard curve of the serial dilution of target and reference DNA. Standard curves for ghtubl and crylAc were constructed for the CRM through serial dilution method (0.01ng, $0.1 \mathrm{ng}, 1.0 \mathrm{ng}, 10 \mathrm{ng}, 100 \mathrm{ng})$ in three repeats for each dilution point. Average $\mathrm{Ct}$ values for each dilution point were plotted to yield standard curves (Fig. 2, 3, 4). 


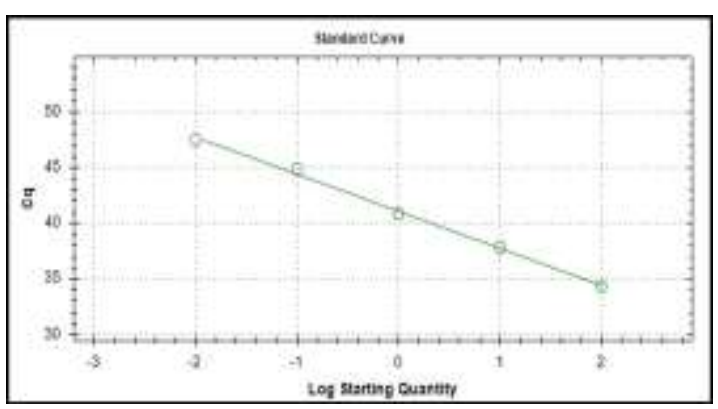

Fig. 2: Dilutions for ghtubl in CRM

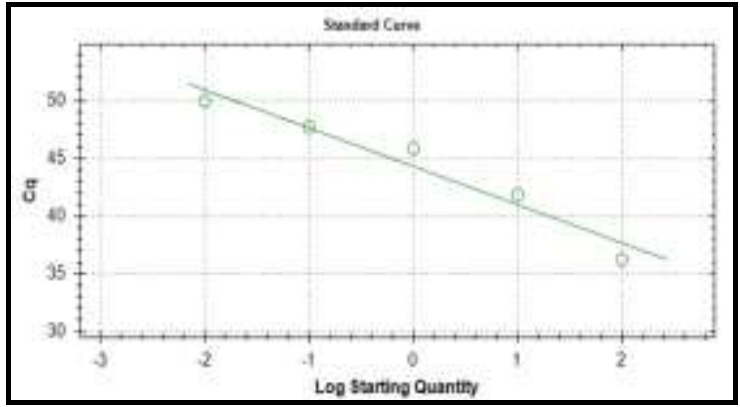

Fig. 3: Dilutions for crylAc in CRM

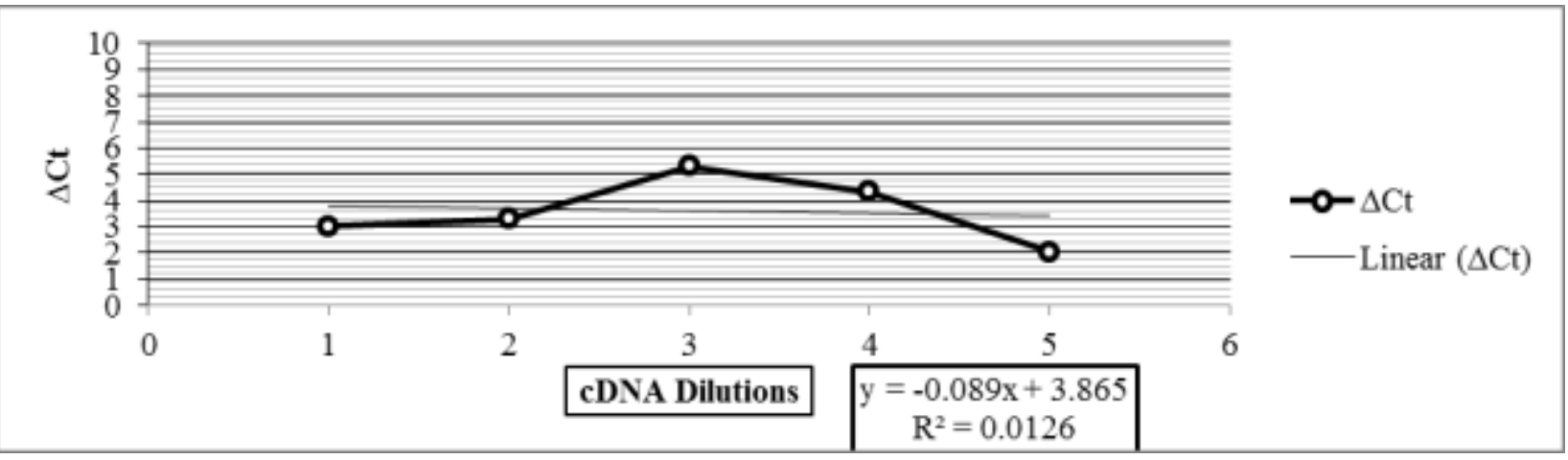

Fig. 4: $\Delta \mathrm{Ct}$ values over the range of dilutions

The $\mathrm{Ct}$ values from the standard curves shown above were used to calculate $\Delta \mathrm{Ct}$ which was later used to draw $\Delta \mathrm{Ct}$ curve and its respective $\mathrm{R}^{2}$ value (table 2 ).

\begin{tabular}{|c|c|c|c|c|c|}
\hline \multirow{2}{*}{ Sr.No. } & \multirow{2}{*}{$\begin{array}{l}\text { Dilution } \\
\text { series }\end{array}$} & \multirow{2}{*}{$\begin{array}{c}\text { QTY as } \\
\text { determined } \\
\text { by } \\
\text { applying } \\
\text { the } \\
\text { equation } 1 \\
\text { (ng) }\end{array}$} & \multicolumn{2}{|c|}{--------'Ct Values-- } & \multirow[t]{2}{*}{$\Delta \mathrm{Ct}$} \\
\hline & & & crylAc & ghtubl & \\
\hline 1 & $0.01 \mathrm{ng}$ & 0.014 & 50.50 & 47.48 & 3.02 \\
\hline 2 & $0.1 \mathrm{ng}$ & 0.07 & 48.19 & 44.91 & 3.28 \\
\hline 3 & $1.0 \mathrm{ng}$ & 0.275 & 46.18 & 40.87 & 5.31 \\
\hline 4 & $10 \mathrm{ng}$ & 4.36 & 42.18 & 37.85 & 4.33 \\
\hline 5 & $100 \mathrm{ng}$ & 234.42 & 36.41 & 34.36 & 2.05 \\
\hline
\end{tabular}

The expression ratio is calculated according to the following equation: sample)

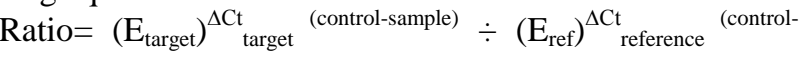

The amplification of crylAc and ghtubl was carried out in separate PCR vials in the same reaction set up in two repeats for each gene and the corrected $\mathrm{Ct}$ values were calculated based upon the respective standard curve as per equations $1 \& 2 . \Delta \mathrm{Ct}$ values were used for determination of the expression ratio (table 3,4 ).

TABLE. III: CT VALUES OF THE TWO GENES FOR EACH TRANSGENIC COTTON VARIETY AND CRM ACCORDING TO THEIR CORRESPONDING STANDARD CURVES BY RT PCR

\begin{tabular}{|c|c|c|c|c|c|}
\hline $\begin{array}{c}\text { Sample } \\
\text { variety }\end{array}$ & Bt666 & Bt886 & CM555 & SL1 & CRM \\
\hline crylAc & 30.58 & 35.21 & 41.79 & 35.48 & 50.93 \\
\hline ghtubl & 32.72 & 35.44 & 42.57 & 35.94 & 57.02 \\
\hline
\end{tabular}

TABLE IV. THE COMPARATIVE EXPRESSION RATIO OF THE CRYIAC IN COTTON VARIETIES

\begin{tabular}{|c|c|c|c|c|c|c|c|c|c|c|c|}
\hline $\begin{array}{c}\mathrm{Sr} \\
\text { No }\end{array}$ & DI & SV & CIC & CIS & $\Delta \mathrm{Ct}_{c r y l A c}$ & GIC & GIS & $\Delta \mathrm{Ct}_{\text {ghtubl }}$ & $\left(\mathrm{E}_{\mathrm{tgt}}\right)^{\Delta \mathrm{Ct}}{ }_{\mathrm{tgt}}$ & $\left(\mathrm{E}_{\mathrm{ref}}\right)^{\Delta \mathrm{Ct}} \mathrm{ref}$ & Ratio \\
\hline 1 & 100 & Bt666 & 30.23 & 30.58 & -0.35 & 31.34 & 32.72 & -1.38 & 1.001 & 1.0040 & 0.997 \\
\hline 2 & 100 & Bt886 & 35.11 & 35.21 & -0.1 & 35.39 & 35.44 & -0.05 & 1.0004 & 1.0001 & 1.000 \\
\hline 3 & 100 & CM555 & 41.75 & 41.79 & -0.04 & 42.24 & 42.57 & -0.33 & 1.0001 & 1.0009 & 1.000 \\
\hline 4 & 100 & SL1 & 35.15 & 35.48 & -0.33 & 36.20 & 35.94 & 0.26 & 1.0013 & 0.9992 & 1.002 \\
\hline 5 & 100 & CRM & 48.92 & 50.93 & -2.01 & 54.84 & 57.02 & -2.18 & 0.92 & 1.022 & 0.90 \\
\hline
\end{tabular}


Abbreviations used in the table denote as follows: $\mathrm{DI}=$ DNA input (ng) SV= Sample variety

$\mathrm{CIC}=\operatorname{cryl} A c$ in the Control $($ Mean $\mathrm{Ct})$

Sample (Mean $\mathrm{Ct}$ )

$\mathrm{GIC}=$ ghtubl in the control (Mean $\mathrm{Ct}) \quad \mathrm{GIS}=$ ghtubl in

the Sample (Mean Ct)

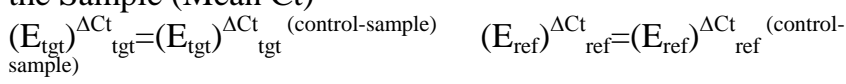

The transgene crylAc has been introduced into a multitude of crop plants such as cotton, maize, soybean, poplar etc. for resistance against insect pests particularly $H$. armigera. A consistently optimum expression of the transgene is the main goal of transgenic crop breeding so that the subsequent progenies of the plants exhibit the similar level of introduced characteristics [8]. The expression profile of a transgene depends upon multiple factors such as DNA methylation, site of integration and the variable number of transgene copies [4] which depend upon the transgenic approach applied e.g. agrobacterium mediated method, particle bombardment. It leads to a variable production of the desired protein in transgenic plants [5]. In this study, the expression ratio of the transgene $c r y l A c$ in different varieties exhibits approximately an equal level as compared with the certified reference material. RT qPCR coupled with standard curve method yields a robust assay to sort out the transgenic cotton from the conventional non GM varieties/unauthorized varieties along with a determination of their expression profile.

\section{CONCLUSION}

The expression level of crylAc is found at par with ghtubl indicating the presence of a single copy of crylAc. However whether the toxin expression is sufficient enough to ward off the damaging insects can only be determined through further proteomic quantification and determination of the $\mathrm{LD}_{50}$ assays.

\section{REFERENCES}

[1] Ceron, J., A. Ortiz, R. Quintero, L. Guereca, and A. Bravo (1995). Specific PCR primers directed to identify cryI and cryIII genes within a Bacillus thuringiensis strain collection, Applied and Environmental Microbiology 61: 3826-3831.

[2] H. Naushaba, A.C. Sarah, S. A. Shahin, A.F. David, and W. Gary. (2014). Global transcript and phenotypic analysis of yeast cells expressing Ssa1, Ssa2, Ssa3 or Ssa4 as sole source of cytosolic Hsp70Ssa chaperone activity. BMC Genomics 415:194

[3] I. Yang, A. Pan, K. Zhang, B.Qain, J.Chen, and D. Zhang. (2005). Qualitative and Quantitative PCR Methods for event specific detection of genetically modified cotton MON1445 and MON531. Transgenic Research 14: 817-831. https://doi.org/10.1007/s11248-005-0010-z

[4] M.R. Ahuja, and M. Fladung. (2014). Tree Integration and inheritance of transgenes in crop plants and trees. Genetics \& Genomes. 10: 779. https://doi.org/10.1007/s11295-014-0724-2

[5] M.R. Liou, Y.W. Huang, C.C. Hu, N.S. Lin, and Y. H. Hsu. (2014). A dual gene-silencing vector system for monocot and dicot plants. Plant Biotechnology Journal;12(3):330-43. https://doi.org/10.1111/pbi.12140

[6] S. Zhang, D. Zhang, Y. Liu, X. Luo, J. E. Cheng, and P. Jing. (2013). Development of a Real-time RT-PCR Method for Rapid Detection and Quantification of Southern Rice Black-streaked Dwarf Virus in Rice. Journal of Plant Pathology \& Microbiology. 4:187 https://doi.org/10.4172/2157-7471.1000187
[7] Xue-Bao, L., C. Lin, C. Ning-Hui, and L. Jian-Wei (2002). Molecular characterization of the cotton ghtubl gene that is preferentially expressed in fiber1, Plant Physiology 130: 666-674. https://doi.org/10.1104/pp.005538

[8] Z. Yuwen, L. Yan, Z. Jie, W. Guoying, W. Jianhua, and L. Yunjun. (2015). Assessment of transgene copy number and zygosity of transgenic maize overexpressing Crylle gene with SYBR ${ }^{\circledR}$ Green qRT-PCR . In Vitro Cellular \& Developmental Biology - Plant. 51: 125.

https://doi.org/10.1007/s11627-014-9658-5 